\title{
Relacja pacjent-personel medyczny w interpretacjach użytkowników forum internetowego Moja Cukrzyca
}

\author{
Relations between patients and medical personnel in the opinions of users \\ of the internet forum Moja Cukrzyca (My Diabetes)
}

\author{
Halina Nowakowska ${ }^{1 凶}$, Małgorzata Lewartowska-Zychowicz ${ }^{2}$ \\ ${ }^{1}$ Gdański Uniwersytet Medyczny, Katedra Pielęgniarstwa, Pracownia Pedagogiki i Dydaktyki Medycznej, ul. Dębinki 7, 80-210 Gdańsk \\ Medical University of Gdańsk, Department of Nursing, Laboratory of Pedagogy and Medical Didactics \\ ${ }^{2}$ Uniwersytet Gdański, Instytut Pedagogiki, ul. Bażyńskiego 4, 80-309 Gdańsk \\ University of Gdańsk, Institute of Pedagogy \\ $\triangle$ halina.nowakowska@gumed.edu.pl
}

\begin{abstract}
Diabetes, universally regarded as an epidemic disease of modern times, is a serious health and economic problem worldwide. According to the International Diabetes Federation, by 2040 the number of people suffering from the disease around the world will have risen to 642 million. The most important element of the treatment process of every disease is a good cooperation between the patients and their treatment team, including following the recommendations formulated by the doctor, nurse, dietician or any other members of that interdisciplinary team. The following article focuses on the issue of the interpersonal communications occurring between the members of the therapeutic team and their patients, analysed from the perspective of
\end{abstract}

\section{ABSTRAKT}

Cukrzyca, uznawana obecnie za epidemię naszych czasów, stanowi poważny problem zdrowotny i ekonomiczny na całym świecie. Według danych opracowanych przez Międzynarodową Federację Diabetologiczną (International Diabetes Federation) do 2040 r. liczba chorych na cukrzycę na świecie wzrośnie nawet do $642 \mathrm{mln}$. Najistotniejszym elementem procesu leczenia każ dego schorzenia jest dobra współpraca chorego z zespołem terapeutycznym, a także przestrzeganie zaleceń formułowanych przez lekarza, pielęgniarkę, dietetyka oraz innych członków zespołu interdyscyplinarnego, sprawującego opiekę nad pacjentem.

Niniejszy artykuł porusza problematykę relacji zachodzących między członkami zespołu terapeutycznego, badaną users of the diabetes internet forum Moja Cukrzyca (My Diabetes). During the research, the method of 'pure' netnography was used. The data analysed in the article were taken from the first research stage which consisted of analysing the for um posts, without any interaction with its users.

In the context of the analyzed posts, it turned out that the therapeutic personnel did not constitute a sufficient source of professional and emotional support for the forum users. This supportive role was often taken over by other diabetic patients, by sharing knowledge and conveying reassurance and comfort, thus enabling the forum users to deal more easily with diabetes. Keywords: diabetes; interdisciplinary team; interpersonal communication; barriers in interpersonal communication.

\section{WSTĘP}

Przedmiotem zainteresowania niniejszego artykułu są interpretacje relacji pacjent-personel medyczny konstruowane przez użytkowników forum internetowego Moja Cukrzyca. Motywem podjęcia tej kwestii jest odczuwalny niedostatek badań poświęconych indywidualistycznej perspektywie ujmowania zagadnienia radzenia sobie z chorobą, jaką jest cukrzyca. Kontekstem analizy tej kwestii będzie proces pozyskiwania przez chorych informacji o zasadach postępowania z cukrzycą

z perspektywy interpretacji konstruowanych przez użytkowników forum internetowego dla diabetyków Moja Cukrzyca. W badaniu została wykorzystana metoda „czystej” netnografii. Analizowane w artykule dane pochodzą z pierwszego etapu procesu badawczego, który polegał na analizie wpisów na forum, bez nawiązywania kontaktu z jego uży tkownikami.

W kontekście cytowanych wypowiedzi okazuje się, że zespół terapeutyczny nie stanowi dla forumowiczów źródła wsparcia emocjonalnego. Funkcję te przejmują inni chorzy, dostarczający forumowiczom owego wsparcia, swoistego komfortu i poczucia bezpieczeństwa, dzięki któremu jest im łatwiej radzić sobie z życiem z cukrzycą.

Słowa kluczowe: cukrzyca; zespół interdyscyplinarny; komunikacja interpersonalna; bariery w komunikacji interpersonalnej. w relacji z personelem medycznym, interpretowany przez nich $\mathrm{w}$ wypowiedziach na tytułowym forum.

\section{SPOŁECZNOŚCI INTERNETOWE I PROCES UCZENIA SIĘ FORUMOWICZÓW}

Rewolucja technologiczna schyłku XX w. doprowadziła do powstania najpierw komputerów osobistych, a następnie urządzeń mobilnych, dzięki którym ogromne rzesze ludzi 
zyskały stały dostęp do zasobów internetu. W rezultacie tego sposoby ich społecznego funkcjonowania zaczęły ulegać gwałtownym przekształceniom uwarunkowanym przez proces migrowania z przestrzeni realnej do wirtualnej, stającej się głównym środowiskiem ich życia. Początkowo internet był jedynie miejscem pozyskiwania i wymiany informacji, zamieszczanych głównie przez profesjonalistów z różnych dziedzin. Obecnie jest najbardziej egalitarną przestrzenią, w której każdy użytkownik może być jednocześnie odbiorcą i twórcą treści, niezależnie od tego, jaki posiada zasób wiedzy o technologiach informatycznych, jakiej jest profesji oraz w jakim miejscu żyje, mieszka i pracuje. Jest najbardziej interaktywnym narzędziem komunikacji międzyludzkiej. Jego użytkownicy tworzą blogi, piszą posty, produkują filmy, recenzują produkty, komentują, dzielą się wiedzą, opiniami, wspierają się i motywują do działania. Internet stał się najbardziej wydajną, najbardziej różnorodną i powszechnie dostępną platformą komunikacji międzyludzkiej. W jego przestrzeni powstają społeczności wirtualne konstruowane wokół różnych światopoglądów, celów i praktyk, w których ludzie zaspokajają swoje potrzeby. Jedną z nich są społeczności forumowiczów, ludzi tworzących platformy wymiany informacji, poglądów czy przekonań, dzięki którym rozwiązują swoje problemy życiowe i zawodowe. Fora stają się w tym kontekście nową, coraz bardziej znaczącą przestrzenią ludzkiego uczenia się, stanowiącą nie tylko dopełnienie, ale coraz częściej alternatywę dla tradycyjnego uczenia się „ludzi księgi”. Tytułowe forum jest przykładem takiej przestrzeni wirtualnej, której użytkownicy wspierają się wzajemnie w swoim życiu z cukrzycą, ale przede wszystkim uczą się jedni od drugich tego, jak z nią żyć na co dzień. Ten sposób uczenia się o funkcjonowaniu z cukrzycą nasuwa pytania o relacje między chorym a personelem medycznym, który do niedawna był jedynym źródłem informacji na ten temat. Będziemy poszukiwać odpowiedzi na nie w interpretacjach konstruowanych przez forumowiczów.

\section{ŻYCIE Z CUKRZYCA - PERSPEKTYWA MEDYCZNA VERSUS PERSPEKTYWA SPOŁECZNA}

Cukrzyca jest obecnie uznawana za epidemię naszych czasów, jedną z pięciu najczęstszych przyczyn zgonów w krajach rozwiniętych. To jeden z najpoważniejszych problemów zdrowotnych i ekonomicznych na świecie. Według danych Światowej Organizacji Zdrowia w 2015 r. liczba chorych na cukrzycę na świecie wynosiła ok. 415 mln, a wg Międzynarodowej Federacji Diabetologicznej (International Diabetes Federation) do 2040 r. wzrośnie nawet do $642 \mathrm{mln}$ [1]. W Polsce na cukrzycę choruje ok. 2 mln osób. U połowy chorych dotkniętych cukrzycą typu 2 nie jest ona zdiagnozowana, w związku z czym nie jest też leczona [2]. Terapia cukrzycy pochłania rocznie ok. 2,5 mld zł, z czego $20 \%$ to koszty związane z leczeniem przewlekłych powikłań tej choroby. Niewielki odsetek chorych (kilka procent) realizuje terapię podobną do tej, która podyktowana jest najnowszymi standardami diabetologicznymi. Polscy chorzy, zwłaszcza zamieszkujący mniejsze ośrodki, mają utrudniony i ograniczony dostęp do lekarzy specjalistów. Ponadto standardy edukacji terapeutycznej, która jest integralnym elementem procesu leczenia i opieki nad chorym, są niezadowalające; brakuje systemowych rozwiązań regulujących te kwestie [3].

Cukrzyca jest chorobą przewlekłą, rozumianą w ujęciu klinicznym jako wszelkie zaburzenia lub odchylenia od normy, które maja jednq lub więcej z następujacych cech charakterystycznych: sq trwałe, pozostawiaja po sobie inwalidztwo, spowodowane sq nieodwracalnymi zmianami patologicznymi, wymagajq specjalnego postępowania rehabilitacyjnego albo według wszelkich oczekiwań wymagać będa długiego okresu nadzoru, obserwacji czy opieki [4]. Jak widać, perspektywa kliniczna nie podejmuje całego szeregu jednostkowych i społecznych kontekstów choroby przewlekłej, przez co jej ogląd jest zawężony i wybiórczy. Dlatego jej dopełnieniem może być perspektywa nauk społecznych, która pozwala na uzupełnienie klinicznego oglądu choroby o ogląd osoby chorującej kształtujący się w konkretnym otoczeniu społecznym. W jego kontekście chodzi bowiem nie tyle o chorobę, ile o chorowanie, co pozwala na analizowanie choroby przewlekłej jako swoistego ludzkiego doświadczenia, które jest przeżywane w określonym kontekście społeczno-kulturowym. Wydaje się, że takie wiązanie różnych perspektyw może być obiecujące nie tylko z perspektywy poznawczej, ale również terapeutycznej, ponieważ ogląd nauk medycznych, skoncentrowany na przyczynach, objawach i leczeniu choroby, może być wzbogacany o rekonstruowanie/rozumienie doznań, wewnętrznych przeżyć osoby chorującej. W tym ujęciu integralnie pojmowane chorowanie i proces leczenia stają się doświadczeniem biograficznym człowieka, w które jest on w pełni zaangażowany [5].

Perspektywa nauk społecznych pozwala także na równoczesne ujmowanie choroby i leczenia jako zjawiska społecznego i jako doświadczenia jednostkowego, które ma swoje przełożenia na ludzkie funkcjonowanie. W pierwszym kontekście proces chorowania i leczenia jest analizowany w związku z procesami naznaczania społecznego. $W$ odniesieniu do niego choroba przewlekła jest badana jako przyczyna stygmatyzacji i wykluczenia społecznego. Wykluczenie owo może być realizowane w formie ekskluzji fizycznej, strukturalnej czy też normatywnej. Osoby doświadczające z różnych względów wykluczenia są skłonne do wycofywania się z życia społecznego, rezygnowania ze swoich planów na przyszłość i orientowania się na teraźniejszość, cechuje je zwątpienie w siebie, fatalizm. Są one izolowane społecznie i - w konsekwencji - deprywowane w różnych obszarach swojego życia [6]. Doświadczenie stygmatyzowania nie pozostaje również bez wpływu na zaangażowanie chorego w proces leczenia choroby.

W drugim kontekście procesy chorowania i leczenia są analizowane z perspektywy indywidualnego doświadczenia człowieka. W tym ujęciu chorobę - jak wskazują Corbin i Strauss można ulokować w kontekście ludzkiego doświadczenia, jakim jest cierpienie z nią związane. Corbin i Strauss używają koncepcji trajektorii cierpienia Schütza, aby wyjaśnić linię rozwojową choroby. Ich zdaniem na trajektorię cierpienia składają się fazy pretrajektorii, prewencyjna, początku, ostra (wymagająca interwencji lekarza), a następnie zdrowienia, stabilizacji 
(rozumianej jako stan remisji lub braku pogorszenia kondycji zdrowotnej) lub niestabilności (utożsamianej z fazą terminalną) [7]. W ich kontekście równolegle z rozwojem choroby chory poddaje ją refleksji z perspektywy dotychczasowych, sprawdzonych sposobów swojego funkcjonowania, które się wyczerpują. Podejmuje próby definiowania siebie i swojej sytuacji na nowo. Choroba ujawnia wówczas swój wymiar egzystencjalny, ponieważ dotyczy całokształtu „ja”, towarzyszą jej pytania „dlaczego ja?”, ,jaki jest sens mojej choroby?”. Te przemyślenia prowadzą chorego do kilku możliwych rozwiązań: pogodzenia się z trajektorią, jej odrzucenia, przyjęcia postawy głębszej solidarności z ludźmi z najbliższego otoczenia lub wrogości wobec nich. Aby opuścić trajektorię, człowiek dotknięty cierpieniem musi podjąć działania polegające na głębokiej rekonstrukcji swojej tożsamości i wykształceniu nowych sposobów postrzegania rzeczywistości i nowych sposobów reagowania na nią [8]. Dopiero w odniesieniu do nich angażuje się w terapię. Ten rodzaj pracy chorego nad chorobą nabiera wymiaru humanistycznego - przekracza bowiem pracę stricte medyczną, a pacjent staje się podmiotem interakcji z personelem medycznym [9]. Dlatego wzięcie pod uwagę całego skomplikowania sytuacji chorego oraz podłoża tworzenia się jego osobistego zaangażowania może mieć niebagatelne skutki dla przebiegu i postępów w leczeniu.

Na gruncie nauk medycznych wyróżnia się trzy modele terapeutyczne leczenia schorzeń przewlekłych: biomedyczny, holistyczny i koncyliacyjny, które na różne sposoby odnoszą się do podmiotowości osoby chorującej.

Model biomedyczny, który stanowi jedną z pierwszych koncepcji zdrowia, pozostaje pod wpływem kartezjańskiej idei ciała jako instrumentu, przyrządu, którym posługuje się duch. Kartezjusz wyraził to słowami: Bóg ukształtował nasze ciało jako maszynę i chciał, aby ona funkcjonowała w charakterze uniwersalnego narzędzia. (...) Ja jestem czymś różnym od mego ciała i bez niego mogę istnieć [10]. Kartezjańska idea dualizmu ciała i umysłu ukształtowała pole intelektualne kultury zachodniej na wiele lat i przyczyniła się do dynamicznego rozwoju nauki, w tym w szczególności nauk medycznych. Równocześnie jednak skoncentrowała uwagę klinicystów jedynie na problemach ciała, które traktowano jako całkowicie rozdzielne od sfery psychiki człowieka. Ujmowanie ciała jako swoistej maszyny pozwoliło traktować wszelkie zaburzenia jego funkcjonowania jako chorobę [11]. Usunęło natomiast z pola widzenia cierpiącego na nią człowieka, jego sferę psychiczną i środowisko, w którym przebywa. W odniesieniu do problematyki leczenia zwolennicy tego modelu koncentrują się na analizie wyników badań oraz poszukiwaniu i niwelowaniu fizycznych objawów choroby, pomijają natomiast zdrowotne konsekwencje emocji towarzyszących chorowaniu. Wynika to z przyjęcia kartezjańskiego założenia o rozdzielności ciała i duszy, w kontekście którego emocje są emanacją psychiki i jako takie nie mają związku ze stanem zdrowia ciała.

Rozwój psychologii doprowadził do zakwestionowania modelu biomedycznego. Badania realizowane przez psychologów pokazały bowiem, że sfera psychiczna, a w szczególności umiejętność radzenia sobie z emocjami, jest czynnikiem znacząco wpływającym na zdrowie i jego jakość w ciągu całego życia człowieka. Dalsze osłabienie modelu biomedycznego ma związek z odkryciem powiązań między układem odpornościowym a ośrodkowym układem nerwowym, następnie zaś zidentyfikowaniem licznych chorób psychosomatycznych [12]. W ich kontekście nie do utrzymania okazała się idea niezależności sfery ciała i ducha. Dlatego w praktyce leczniczej wyłonił się nowy model terapeutyczny, umocowany w holistycznej koncepcji zdrowia. Stanowi on odpowiedź na potrzebę całościowego spojrzenia na człowieka w chorobie, z uwzględnieniem jego sfery psychicznej, a nawet środowiska, w którym żyje [13]. Istotą tego modelu jest postrzeganie każdego chorego jako indy widualności, niepowtarzalnej jednostki, która wymaga dostosowania proponowanej terapii choroby do osobniczych potrzeb i możliwości. Terapia służy w związku z tym przywróceniu osobowej harmonii na poziomie biologicznym, psychicznym i społecznym [14]. Aby to było możliwe, konieczne jest wzięcie pod uwagę w procesie terapeutycznym wszystkich elementów, które składają się na funkcjonowanie człowieka, bowiem wszystkie one kształtują jego stosunek do choroby, sposób realizowania zalecanej terapii oraz szanse potęgowania zasobów własnego zdrowia [15].

Trzeci model terapeutyczny, wykorzystywany w leczeniu, jest nazywany koncyliacyjnym. Istotą tego podejścia w terapii jest uznawanie chorego za swoistego eksperta w zakresie własnej choroby, który najwięcej wie na jej temat. Zwolennicy tego podejścia równie wielką uwagę przywiązują do czynników behawioralnych procesu leczenia (strategie radzenia sobie z chorobą), jak i do czynników poznawczych (doświadczania choroby przez pacjenta) oraz czynników socjokulturowych (uznawane i stosowane w społeczeństwie mechanizmy wsparcia w chorobie, przyjęty system wartości). Cechą charakterystyczną modelu koncyliacyjnego jest w związku z tym ścisła współpraca pacjenta i zespołu terapeutycznego z instytucjami wspierającymi proces leczenia, takimi jak opieka społeczną czy ośrodki terapii behawioralnej [16].

Wskazane modele terapeutyczne układają się w kontinuum obrazujące stopniowe przechodzenie w praktyce medycznej od rozdzielnego do zintegrowanego ujmowania człowieka jako istoty biologiczno-psychiczno-społecznej, która jest kompetentnym uczestnikiem swojego chorowania. Ten drugi sposób ujmowania człowieka w praktyce medycznej jest pokłosiem przenoszenia dorobku nauk społecznych na grunt praktyki medycznej i terapeutycznej.

\section{DOŚWIADCZANIE CHOROBY PRZEWLEKŁEJ - METODOLOGICZNE WSKAZANIA DLA BADAŃ WŁASNYCH}

Podjęta próba łączenia perspektywy klinicznej z perspektywą nauk społecznych odsyła do bogatej tradycji amerykańskiej szkoły metodologii jakościowej, która wyrosła na sformułowanym przez Schütza przeświadczeniu o tym, że zasadniczym celem nauk społecznych jest eksploracja rzeczywistości społecznej na podstawie doświadczenia życia codziennego 
jednostki, a tło życia ludzkiego, rozumiane jako relacje z otoczeniem, przeżywanie codzienności, powinno stanowić ważny obszar zainteresowań badaczy społecznych [17]. W ten kontekst wpisują się prace licznych amerykańskich badaczy jakościowych, którzy badają doświadczenia pacjentów. Jedną z nich jest Charmaz, profesor socjologii Sonoma State University, badaczka doświadczania choroby przewlekłej. W kontekście jej ustaleń przebieg jednostkowego doświadczenia choroby przewlekłej można traktować jako odpowiadający etapom klinicznie rozumianego schorzenia przewlekłego. I tak pierwszą fazę choroby rozpoczyna zwykle nagłe zdarzenie przerywające ciągłość życia jednostki, $w$ wyniku którego odczuwa ona załamanie dotychczasowego sposobu przeżywania codzienności. W fazie drugiej, o charakterze chronicznym, jednostka ma do czynienia ze stałością następstw choroby, które wpisują się w jej codzienność, wymuszając jej reorganizację. Trzeci etap, który Charmaz nazywa „pogrążeniem w chorobie”, jest jednoznaczny z całkowitą zmianą codzienności, uwzględniającą nową rzeczywistość choroby przewlekłej. Analizując doświadczenia chorych, autorka wskazuje skalę ograniczeń, jakie stają się ich udziałem: utratę kontroli na własnym ciałem i przebiegiem procesów fizjologicznych, poczucie uzależnienia od innych, poczucie bycia ciężarem dla najbliższego otoczenia, obniżoną samoocenę czy też społeczną izolację [18].

Przyjęty przez Charmaz kontekst indywidualnego doświadczenia choroby może być inspiracją do badania procesu terapeutycznego z perspektywy chorych. Jednym z jego kluczowych, chociaż wciąż niedocenianych aspektów, będzie w tym ujęciu relacja między pacjentem a personelem medycznym. Najistotniejszym bowiem elementem procesu leczenia każdego schorzenia, a zwłaszcza przewlekłego, nieuleczalnego, jest dobra współpraca między chorym a zespołem terapeutycznym. Współpraca ta musi być jednak oparta na głębokiej świadomości cech i przebiegu procesów komunikacyjnych, na całościowym podejściu do sytuacji zdrowotnej, psychicznej i społecznej chorego oraz na uwzględnieniu jego osobistego doświadczenia chorowania. W tym kontekście sukces terapii okazuje się uzależniony nie tyle od kompetencji zespołu czy zdyscyplinowania pacjenta, ile od relacji, które nawiązują się między nimi. Stąd głównym obszarem zainteresowania stały się dla nas relacje kształtujące się między chorym a zespołem terapeutycznym, który sprawuje nad nim opiekę.

Interdyscyplinarny zespół terapeutyczny, który sprawuje opiekę nad przewlekle chorym, można analizować z perspektywy tzw. teorii systemów złożonych. Pojęcie to pochodzi $z$ terenu nauk przyrodniczych i technicznych, ale od dawna jest z powodzeniem przenoszone na grunt nauk społecznych. Systemy złożone to struktury składające się z wielu połączonych i oddziałujących na siebie części. Cechą systemu złożonego jest trudność ustalenia wewnętrznych granic poszczególnych jego części, które same także mogą być podsystemami złożonymi. Ma on także charakter dynamiczny, zmienia się $\mathrm{w}$ czasie, a relacje $\mathrm{w}$ jego obrębie są nieliniowe, tzn. że małe zakłócenia początkowe mogą przynieść w efekcie końcowym duże zmiany, zmiany współmierne lub też mogą nie przynieść żadnych zmian [19]. Dlatego badanie systemów złożonych

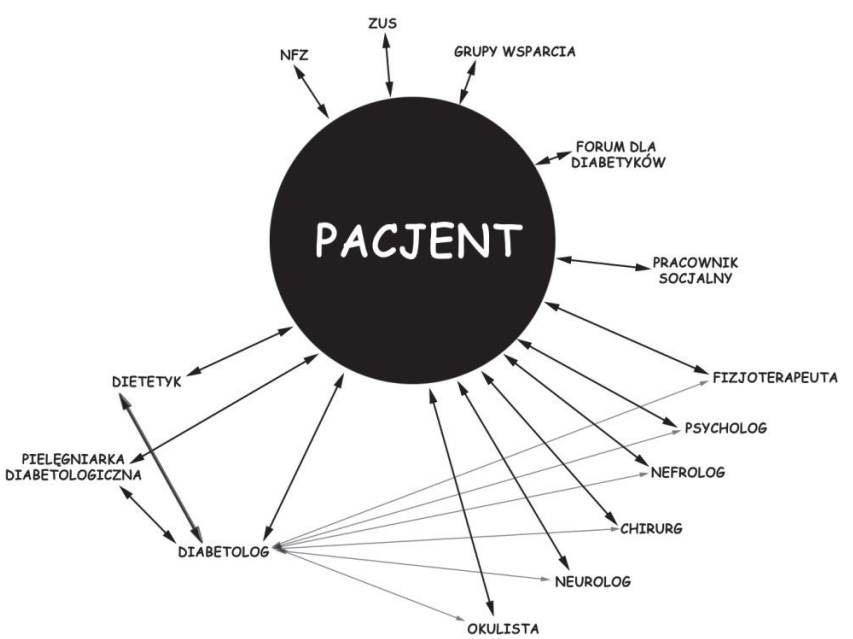

RYCINA 1. Relacje między członkami zespołu interdyscyplinarnego

polega na badaniu zachodzących $w$ jego obrębie interakcji. Wynika to z ich emergencji, czyli właściwości polegającej na tym, że zachowania systemu jako całości nie można zrozumieć za pośrednictwem badania jego poszczególnych części składowych.

W odniesieniu do zespołu terapeutycznego, który sprawuje opiekę nad przewlekle chorym, można zatem mówić o interakcjach zachodzących między pacjentem, lekarzem, pielęgniarką, położną, dietetykiem, psychologiem, fizjoterapeutą, rehabilitantem, pracownikiem socjalnym, a nawet grupami wsparcia czy instytucjami takimi jak NFZ. Na rycinie 1 przedstawiono kierunki potencjalnie zachodzących między nimi relacji.

Przedstawione na rycinie 1 linie ciemniejsze oddają silnie akcentowane relacje wewnątrz systemu. Z kolei linie jaśniejsze oznaczają relacje słabsze. Im więcej linii, a w szczególności linii ciemniejszych, tym wyższa efektywność komunikacji między członkami zespołu, a tym samym - lepsza jakość opieki nad chorym przewlekle. Współpraca zespołu rozumianego jako system, $w$ którego centrum znajduje się pacjent, oparta na licznych interakcjach między jego członkami, zapewnia kompleksowość działania i podnosi jego efektywność. Podobnie jest w przypadku zespołu terapeutycznego, opiekującego się chorym na cukrzycę. Współpraca pozwala bowiem na wykorzystywanie potencjału każdego elementu sytemu, dzięki czemu wzrasta szansa na skonstruowanie najbardziej obiecującej strategii działania terapeutycznego opartej na podziale zadań i sprawnym przepływie informacji. Stąd problematyka relacji zachodzących między członkami zespołu terapeutycznego, badana z perspektywy interpretacji konstruowanych przez użytkowników forum internetowego www.mojacukrzyca. org.pl, stała się przedmiotem niniejszego zainteresowania badawczego.

W badaniu wykorzystano metodę „czystej” netnografii. Netnografia to termin wprowadzony do literatury metodologicznej przez Kozinetsa na oznaczenie badań etnograficznych prowadzonych online. Wydzielenie netnografii jako specyficznej formy etnografii jest oparte na założeniu, że skoro doświadczenia społeczne w sieci są znacząco odmienne od doświadczeń społecznych w realu, to i praktyka badania etnograficznego, 
realizowanego w bezpośrednim kontakcie, i badania realizowanego za pośrednictwem internetu musi się różnić. Różnice te dotyczą sposobu nawiązywania kontaktu ze społecznościami internetowymi, sposobu uczestniczenia w nich przez badacza, sposobu gromadzenia danych i ich opracowywania. W netnografii wykorzystuje się też nowe metody, które nie były stosowane w klasycznej etnografii, takie jak eksploracja danych (data mining) pozwalająca na docieranie do danych publicznie dostępnych w sieci.

Metoda „czystej” (niezależnej) netnografii polega na wykorzystywaniu wyłącznie komputerowo zapośredniczonych danych (...), brakuje w niej gromadzenia danych za pomoca osobistych kontaktów oraz elementów interakcji bezpośredniej [20]. Analizowane w artykule dane pochodzą z pierwszego etapu zainicjowanego procesu badawczego, który polegał na analizie wpisów na forum www.mojacukrzyca.org.pl, bez nawiązywania kontaktu z jego użytkownikami.

\section{WYNIKI}

\section{Relacja między pacjentem a personelem medycznym w interpretacjach użytkowników forum Moja Cukrzyca}

Cukrzyca jest jedną z wielu chorób przewlekłych. Jej istotą są zaburzenia w wydzielaniu insuliny, hormonu produkowanego przez trzustkę. Insulina kontroluje sposób postępowania organizmu ludzkiego ze spożywanymi pokarmami, ich spalanie lub magazynowanie. Gdy trzustka produkuje jej zbyt mało, nadmiernie wzrasta poziom cukru we krwi, co wyzwala kaskadę patologicznych następstw, np. nasilone pragnienie, uczucie zmęczenia, utratę przytomności, a w fazie odległej również choroby serca, oczu, nerek, choroby nowotworowe czy zmiany organiczne powodujące konieczność amputacji palców stóp, całych stóp lub podudzi. Dlatego nie można żyć z niedoborem insuliny, a dolegliwości odczuwane przez chorego, przebieg schorzenia oraz skutki uboczne leczenia są wyjątkowo traumatyczne. Dobrze kontrolowana cukrzyca pozwala jednak na życie o porównywalnej jakości i długości jak w przypadku osoby zdrowej. Wyjątkowość cukrzycy polega jednak na tym, że ciężar jej leczenia spoczywa przede wszystkim na barkach chorego. Pacjent jest partnerem, a w zasadzie rdzeniem zespołu terapeutycznego, może praktycznie samodzielnie realizować proces terapii, wymaga to jednak jego dobrego przygotowania oraz motywacji. Chory, który pozyskał i ma dobrze ugruntowaną wiedzę o istocie i przebiegu choroby oraz roli farmakoterapii, diety i wysiłku fizycznego w kontroli glikemii, zyskuje samodzielność oraz zadowalającą jakość życia. Byłoby nadużyciem twierdzić, że cukrzyca pozwala na prowadzenie identycznego jakościowo życia, jak to sprzed choroby, niemniej jednak chory może powrócić do poprzednich form aktywności i realizować się w satysfakcjonującym życiu [21].

Warunkiem koniecznym dobrego funkcjonowania z cukrzycą jest jednak poprawna relacja pacjent-lekarz oraz pacjent-pozostali członkowie zespołu terapeutycznego, nacechowana dobrym przepływem informacji, otwartością wzajemnej komunikacji i zaufaniem. 0 postulowanym przebiegu tej relacji lekarz diabetolog wypowiada się w następujący sposób: (...) wyniki leczenia powinno się oceniać wspólnie z chorym, więc zarówno pacjent, jak i lekarz powinni mieć komfortowy dostęp do monitora komputera. (...) Daje to szansę na skrócenie dystansu pomiędzy pacjentem a i lekarzem, szczególnie gdy lekarz i pacjent siedza po tej samej stornie biurka. (...) Dobrze jest, gdy analize rozpoczyna i prowadzi lekarz. Zwykle dokonuje on analizy według własnego „klucza”. (...) Lekarz powinien w tym czasie komentować analizowane przez siebie dane. Po wstępnej weryfikacji problemów w leczeniu powinien przyjść czas na komentarz ze strony pacjenta, jego interpretację ewentualnych niepowodzeń $w$ terapii. (...) Zdarza się, iż pacjent wyraźnie „błądzi”, nie chce przyjąć sugestii terapeutycznych. W takich sytuacjach należy pamiętać o rzetelnym przedstawieniu naszych racji językiem zrozumiałym dla chorego. Pamiętajmy, że nawet najbardziej słuszne wskazówki nie zostanq efektywnie wdrożone przez pacjenta, jeżeli nie będzie on do nich przekonany. Co ważne, przebiegająca $w$ ten sposób wizyta lekarska staje się jednocześnie wizytą „edukacyjnq" [21].

Jako kontrapunkt dla cytowanego ciągu zaleceń można potraktować wypowiedź administratora forum Moja Cukrzyca Jerzego Magiery: Raz zgłosiła się do mnie 31-latka, chorująca na cukrzycę typu 1 od 3 lat. Od swojego diabetologa dostała insulinę i sztywne dawki na każdy posiłek. Kobieta w ogóle nie wiedziała, co to jest wymiennik węglowodanowy, jak prawidłowo przeliczać dawkę insuliny, jak interpretować wyniki. Na tyle, na ile było to możliwe, przeprowadziłem z niq dyskusję, próbujac przybliżyć, wydawać by się mogło podstawowe wiadomości o cukrzycy. Tego nikt wcześniej jej nie przekazał. Nikt nie nauczył podstaw, bez których ciężko żyć z cukrzyca, szczególnie typem 1. Skierowałem ja także do lokalnych organizacji cukrzycowych, gdzie będzie mogła otrzymać pomoc w sposób bezpośredni [22].

Kontrast zaznaczający się w tych wypowiedziach stanowi istotne uzasadnienie wartości podjętego własnego projektu badawczego dotyczącego interpretacji relacji pacjent-personel medyczny przez użytkowników forum internetowego Moja Cukrzyca. Forum to ma bardzo długą, bo już 17-letnią historię. Jego założycielem i administratorem jest diabetyk Jerzy Magiera, który w 2001 r. postawił sobie za cel zintegrowanie środowiska cukrzyków. Aktualnie forum jest obecne w takich mediach społecznościowych jak Facebook, Instagram czy Twitter. W każdym z tych miejsc chorzy mogą pozyskać wielowymiarowe informacje o cukrzycy oraz pomoc w postaci odpowiedzi na każde nurtujące ich pytanie. Obecnie na forum zamieszczonych jest ok. 311 tys. postów, w których poruszanych jest 10010 wątków pogrupowanych tematycznie. Przedmiotem niniejszej analizy były posty dostępne na forum w okresie 1-30 kwietnia 2017 r. w kategorii „Mój lekarz, moja poradnia", które dotyczyły problematyki relacji pacjent-personel medyczny. Ze względu na rozległość materiału empirycznego dokonano jego uporządkowania w rodzaj map semantycznych. Zostały one skonstruowane w trzech kolejnych krokach: pierwszy etap polegał na wyborze z postów pojedynczych słów, fraz i krótkich zdań dotyczących tych samych obszarów znaczeniowych, w etapie drugim zostały utworzone kręgi znaczeniowe, a w etapie trzecim w obrębie owych kręgów wyodrębniono kategorie opisu (ryc. 2). 


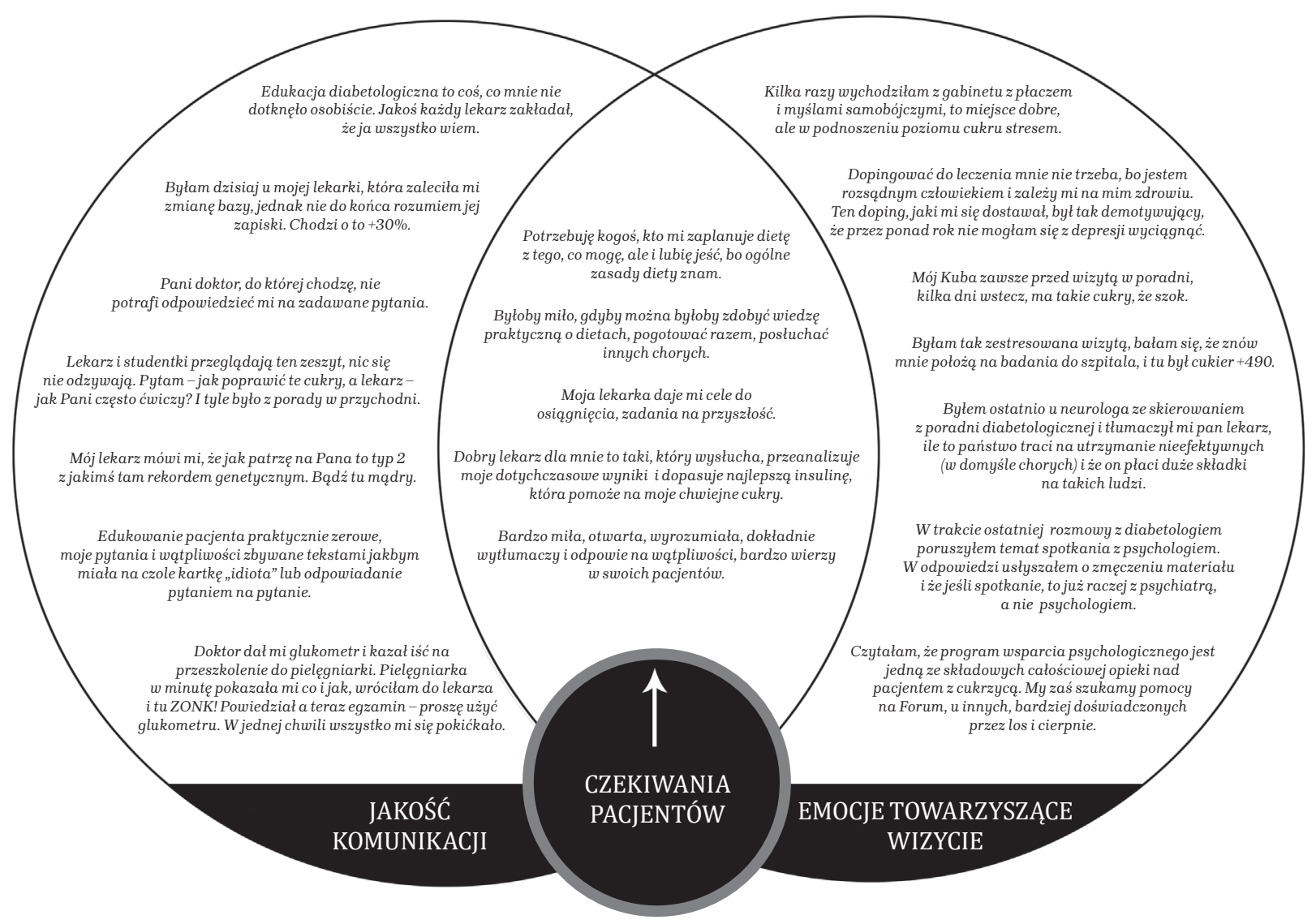

RYCINA 2. Mapa semantyczna wyodrębnionych kręgów znaczeniowych

W analizowanym materiale nie udało się zidentyfikować wypowiedzi odnoszących się do wszystkich członków zespołu terapeutycznego. Użytkownicy forum wypowiadali się najczęściej na temat swojej relacji z lekarzem diabetologiem, sporadycznie na temat relacji z pielęgniarką i psychologiem, natomiast pozostali członkowie zespołu nie pojawiali się w ich wypowiedziach. Stąd zamysł niniejszego badania musiał ulec zdecydowanemu zredukowaniu do kontekstu relacji pacjent diabetologiczny-lekarz/pielęgniarka. Równocześnie jednak nasunęło się pytanie o praktykę opieki nad pacjentem diabetologicznym, która wydaje się w kontekście wypowiedzi forumowiczów znacznie ograniczona w porównaniu z zalecanymi standardami.

Analizowany materiał empiryczny pozwolił na wyodrębnienie dwóch kręgów znaczeniowych - jakość komunikacji i emocje towarzyszące wizycie u lekarza (w poradni), które na rycinie 2 zostały odniesione do werbalizowanych oczekiwań pacjentów. Oczekiwania owe stanowiły punkt wyjścia analiz, ponieważ jakość ich zdefiniowania - jak założono - pozwala forumowiczom dokonać interpretacji relacji pacjent-zespół terapeutyczny. Analiza wpisów wskazuje, że oczekiwania wobec personelu medycznego są jasno i precyzyjnie określone: (...) Moim zdaniem ludzie z lękami powinni być pod troskliwa ciągła opiekq. Powinni mieć kogoś w rodzaju trenera, z którym będa mogli się spotkać kiedy chca, który im poradzi co robić w danej chwili. Innymi słowy powinni się pod kogoś obeznanego podczepić na jakiś czas. Domyślam się, że w naszej rzeczywistości służby zdrowia to raczej mało rzeczywiste.

W obrębie pierwszego kręgu, który nazwano jakością komunikacji, forumowicze wskazali kilka podstawowych barier: niezrozumiały język przekazu, unikanie odpowiedzi na pytania chorego, okazywanie zniecierpliwienia czy też zaniechanie obowiązku informowania pacjenta. Pierwsze ze wskazań dotyczy używania przez lekarza hermetycznego języka, który jest niezrozumiały dla pacjenta niebędącego specjalistą. Dotyczy to w szczególności pacjentów o niezbyt długim stażu chorowania, którym obca jest terminologia związana z cukrzycą. Pozostałe bariery są odmiennej natury, ponieważ związane są z niewłaściwymi zachowaniami/postawami lekarza, które mają zdecydowanie nieprofesjonalny charakter: Moja kolej na wejście do pani doktor przypadła akurat na czas przerwy śniadaniowej pani doktor i pielęgniarek (...). W ramach zemsty chyba pani doktor rozmawiała ze mna jak z kretynka, nie wiedziała, że im bardziej jestem zdesperowana, tym celniejsze moje riposty, więc wizyta nie była miła. Dowiedziałam się, że wszystko robię źle i nie tak, bo kto słyszał żreć 4-5 WW na pierwsze śniadanie, za późno reaguję na niski cukier (nie chodziło o żadna utratę przytomności i cukier rzędu 30, ale o np. 68 czy 64), wysiłek fizyczny nie tak, bo kto się porywa na takie rzeczy z takimi cukrami... itp., itd. Na szczęście tym razem obyło się bez straszenia, 
że jak zajdę w ciążę, to urodzę potworka albo nie urodzę... Prorokini czy co????!!

Wypowiedzi forumowiczów są uderzające w kontekście zadań zespołu, do których zalicza się tworzenie relacji sprzyjających budowaniu motywacji pacjenta do podejmowania wysiłku związanego z dobrą i uważną kontrolą glikemii oraz relacji sprzyjających dobremu klimatowi do nabywania wiadomości o cukrzycy [21]. W materiałach edukacyjnych Polskiej Federacji Edukacji w Diabetologii mowa jest nawet o komunikacji interpersonalnej jako podstawowym ogniwie efektywnej współpracy z pacjentem w nowoczesnej medycynie [23]. Tymczasem jak wskazują wypowiedzi forumowiczów, nie spotykają się oni z takimi standardami opieki.

Drugi wyodrębniony krąg znaczeniowy dotyczył emocji towarzyszących pacjentom podczas wizyty u lekarza/w poradni. W kontekście analizowanych postów okazuje się, że spotkanie z lekarzem jest często dla pacjentów źródłem lęku, frustracji i zniechęcenia: Może mam po prostu pecha i trafiam na zbiorowego PMS-a za każdym razem? (...) Czepianie się i wyzywanie za każde cukrowe odchylenie od normy - po którejś wizycie odpuściłam sobie „prawdziwy” dzienniczek i zaczęłam zapisywać wyniki tak, żeby nie było się do czego przyczepić. Kilka razy wychodziłam z gabinetu z płaczem i myślami samobójczymi. Jak dla mnie to miejsce jest dobre, ale w podnoszeniu poziomu cukru stresem.

W związku z negatywnymi emocjami doświadczanymi $\mathrm{w}$ kontakcie z personelem medycznym forumowicze szukają wsparcia u innych chorych: Jeszcze trochę sobie pomarudzęwybaczcie, ale mam wrażenie, że kiedy mówię komuś, kto nie jest na to chory, to nie jest w stanie mnie zrozumieć, a wygadać się muszę.

Pozdrawiam Was i głowa do góry. Cukrzyca nie jest taka straszna. Żyję normalnie, pracuję i czuję się mimo wszystko szczęśliwy. Nasza postawa i stosunek do cukrzycy jest bardzo ważny. Nie uważajcie, że chorujecie. Jest to gatunek zdrowia, tyle że uwarunkowanego.

\section{WNIOSKI}

W kontekście cytowanych wypowiedzi okazuje się, że zespół terapeutyczny, do którego zadań należy tworzenie przyjaznej atmosfery sprzyjającej przepływowi informacji i uczeniu się pacjenta o funkcjonowaniu z cukrzycą, nie stanowi dla forumowiczów źródła wsparcia emocjonalnego. Funkcję tę przejmują inni chorzy dostarczający forumowiczom owego wsparcia, swoistego komfortu i poczucia bezpieczeństwa, dzięki któremu jest im łatwiej radzić sobie z życiem z cukrzycą [21].

Podsumowując, zgromadzony we wstępnej fazie badań materiał empiryczny pozwala na sformułowanie ostrożnej sugestii, iż prawdopodobnie istnieją pewne przesunięcia, jakie dokonują się w opiece nad pacjentem diabetologicznym, które polegają na przejmowaniu zadań zespołu terapeutycznego przez pacjentów wymieniających się informacjami na temat życia z cukrzycą i dostarczających sobie wzajemnie wsparcia emocjonalnego i motywacji.

\section{PIŚMIENNICTWO}

1. International Diabetes Federation. https://www.idf.org/about-diabetes/ what-is-diabetes.html (12.07.2017).

2. Sieradzki J. Cukrzyca. Kompendium. Gdańsk: Via Medica; 2009. p. 1-12.

3. Leczenie i koszty cukrzycy w Polsce. Raport z badania Desk Research przygotowany dla Polskiego Stowarzyszenia Diabetyków. Warszawa: Millward Brown SMG/KRC; 2007. https://mdtmedical.eu/uploads/1CE858ABE107-4D2B-A659-4C65D8DB3437.pdf (19.07.2017).

4. Shontz FC. Ciężkie choroby przewlekłe. In: Garrett JF, Levine ES, editors. Praktyka psychologiczna w rehabilitacji inwalidów. Warszawa: PZWL; 1972.p. 300.

5. Mazurek E. Choroba w rodzinie. Zastosowanie metodologii teorii ugruntowanej do analizy funkcjonowania rodziny w sytuacji choroby. Fam Forum 2013;3:25-39.

6. Kozak M. Wykluczenie - rozwój - przestrzeń In: Jarosz M, editor. Wykluczeni. Wymiar społeczny, materialny i etniczny. Warszawa: Wydawnictwo ISP PAN; 2008. p. 211.

7. Maksymowicz A. Internet jako wsparcie dla chorych na choroby rzadkie. Media i Społeczeństwo 2016;6:111-21.

8. Kozerska A. Wywiad narracyjny w badaniach nad uczeniem się człowieka dorosłego w kontekście historii jego życia. Edukacja Ustawiczna Dorosłych 2013;2:29-35.

9. Konecki KT. Anselm L. Strauss - pragmatyczne korzenie, pragmatyczne konsekwencje. Przegląd Socjologii Jakościowej 2015;11(1):12-39.

10. Kowalczyk S. Ciało człowieka w refleksji filozoficznej. Lublin: Wyd. KUL, 2009. p. 62.

11. Ostrzyżek A, Marcinkowski JT. Biomedyczny versus holistyczny model zdrowia a teoria i praktyka kliniczna. Probl Hig Epidemiol 2012;93(4):682-6.

12. Sęk H, Ścigała I, Beisert M, Bleja A. Subiektywne koncepcje zdrowia. Wybrane uwarunkowania. Prz Psychol 1992;35(3):351-63.

13. Starzyńska-Kościuszko E. Holistyczna (całościowa) koncepcja zdrowia: zdrowie jako wartość. Humanistyka i Przyrodoznawstwo 2010;16:319-26.

14. Szawarski Z. Mądrość i sztuka leczenia. Gdańsk: Wyd. Słowo/Obraz Terytoria; 2005. p. 60-70.

15. Kowalski M, Gaweł A. Zdrowie - wartość - edukacja. Kraków: Impuls; 2007.

16. Bielecki W, Drygas W. Syndrom choroby funkcjonalnej-socjomedyczny mit czy rzeczywistość? Sztuka Leczenia 2009;18(1-2):57-72.

17. Schütz A. Potoczna i naukowa interpretacja ludzkiego działania. In: Mokrzycki E, editor. Kryzys i schizma. Antyscjentystyczne tendencje w socjologii współczesnej. T. 1, Warszawa: PIW; 1984. p. 176.

18. Charmaz K. Teoria ugruntowana. Praktyczny przewodnik po analizie jakościowej. Warszawa: Wydawnictwo Naukowe PWN; 2013. p. 142.

19. Findeisen W. Struktury sterowania dla złożonych systemów. Warszawa: Oficyna Wydawnicza Politechniki Warszawskiej; 1997. p. 190.

20. Kozinets RV. Netnografia. Badania etnograficzne online. Warszawa: Wydawnictwo Naukowe PWN; 2012. p. 18-262.

21. Benbenek-Klupa T, Klupa T. Osobiste pompy insulinowe: filozofia leczenia i edukacja. Gdańsk: Via Medica; 2015. p. 1-30.

22. Magiera J. Razem w trosce o pacjenta. Życie z Cukrzycą 2016:7.

23. Komunikacja interpersonalna. Jak porozumiewać się skutecznie? Warszawa: Materiał edukacyjny Część 1. Warszawa: Polska Federacja Edukacji w Diabetologii; 2012. http://www.pfed.org.pl/uploads/1/9/9/8/19983953/broszura_komunikacja_interpersonalna_p1.pdf (7.07.2017). 